\title{
Uji Efektifitas Herbisida Atrazin, Mesotrion, dan Campuran Atrazin+Mesotrion terhadap Beberapa Jenis Gulma
}

\section{Trial Effectiveness Herbicides Atrazin, Mesotrion, and Atrazin+Mesotrion Mixture for Certain Types of Weeds}

\author{
Nana Ratna Wati ${ }^{1}$, Dad Resiworo J. Sembodo ${ }^{2}$, dan Herry Susanto ${ }^{2}$ \\ ${ }^{1}$ Mahasiswa Jurusan Agroteknologi Fakultas Pertanian Universitas Lampung \\ ${ }^{2}$ Dosen Jurusan Agroteknologi Fakultas Pertanian Universitas Lampung \\ Jln. Prof. Dr. Soemantri Brodjonegoro No. 1, 35141 \\ Korespondensi:nana_ratnawati@rocketmail.com
}

\begin{abstract}
The aimed of this research was to know the effectiveness of mixing herbicides with active ingredient atrazin and mesotrion in controlling weeds and know the mixture characteristic. This research conducted in the plastic garden house private in Natar, South Lampung and in the Weeds laboratory of Agriculture faculty, Lampung University from June until July 2013. This Research arranged in a Randomized Completely Design (RCD). Treatment consists of three types of herbicides with six level of dosage active ingredient, namely of single herbicides is atrazin $500 \mathrm{gl}^{-1}(0$, 76, 152, 304, 608, and 1.215 ha $\left.\mathrm{g}^{-1}\right)$, mesotrion $50 \mathrm{gl}^{-1}(0,11,22,43,86$, and $172 \mathrm{~g}$ $\left.h \mathrm{a}^{-1}\right)$, and mixed herbicides from atrazin $500 \mathrm{gl}^{-1}+$ mesotrion $50 \mathrm{gl}^{-1}(0,28,56, \mathrm{ID}$ 225, and $450 \mathrm{~g} \mathrm{ha}^{-1}$ ). The target weed were a type of broadleaves (Asystasia gangetica), a type of grasses (Paspalum conjugatum), and a type of sedges (Cyperus kyllingia).Homogenity tested using Bartlet and aditivity tested using Tukey, data analyzed by Analisis of Variance and different median values tested with Least Significant Difference (LSD) level 5\%. Results showed that an active ingredient mixture of atrazin $500 \mathrm{gL}^{-1}+$ mesotrion $50 \mathrm{~g} \mathrm{~L}^{-1}$ has $L D_{50}$ expectation value of 51,48 $\mathrm{g} \mathrm{ha}^{-1}$ and $L D_{50}$ treatment of $257,48 \mathrm{~g} \mathrm{ha} \mathrm{h}^{-1}$ with the co-toxicity value was 0.2 (cotoxicity < 1) until mixture was antagonist.
\end{abstract}

Keywords: Atrazin, mesotrion, herbicide mixture, Multiplicative Survival Model ( $M S M), L D_{50}$

Diterima: 09 Oktober 2014, disetujui 19 Desembe 2014

\section{PENDAHULUAN}

Herbisida merupakan bahan kimia yang dapat digunakan untuk mengendalikan pertumbuhan gulma karena dapat mematikan pertumbuhan atau menghambat pertumbuhan normalnya (Tjitrosoedirdjo et al., 1984). Penelitian mengenai herbisida kimia telah dimulai pada awal abad ke-20 dengan herbisida pertama yang disintesis adalah 2,4-D (Wikipedia, 2014). Karena sifat dari herbisida yang efektif, selektif, dan sistemik maka petani dengan cepat menerima penggunaan herbisida dalam kegiatan pengendalian gulma (Sembodo, 2010). Namun pemakaian herbisida yang terus-menerus 
tersebut akan meningkatkan jumlah residu herbisida dalam tanah. Herbisida atrazin merupakan salah satu herbisida dalam kelompok triazin yang mulai banyak digunakan di seluruh dunia pada tahun 1960 namun telah muncul resistensi gulma pada pertengahan tahun 1980. Beberapa dari gulma yang resisten tersebut juga ditemukan gulma yang mengalami resistensi silang terhadap herbisida lainnya (Cousens and Mortimer, 1995). Penggunaan atrazin telah menimbulkan kekhawatiran yang signifikan karena akumulasi yang tinggi dari herbisida tersebut di sungai-sungai (Cox, 2001). Selain itu bedasarkan penelitian pada $65 \%$ wilayah sampel di sekitar Great Barrier Reef, atrazin berada di peringkat nomor dua dengan persentase residu sebesar 52\% (Lewis et al., 2012). Cara untukmengatasiresistensigulma yang telah terjadi dapat dilakukan dengan mengubah formulasi dari herbisida tersebut atau dengan cara melakukan pencampuran herbisida.

Mesotrionadalahjenis herbisidabarudalam kelompoktriketondanefektifterhadapspesies yang resisten terhadap herbisida triazin dan herbisida penghambat ALS (Acetolactate synthase). Secara umum mesotrion bertindak sebagai penghambat pigmen (Hanh and Paul, 2002). Mesotrion terdaftar sebagai herbisida baru yang diaplikasikan pratumbuh untuk pengendalian gulma dengan menghambat pembentukan dioksigenase 4-hydroxyphenylpyruvate (HPPD) pada tahun 2001 bersama dengan herbisida topramezone pada tahun 2005, dan tembotrione pada tahun 2007. Dalam penggunaannya, telah direkomendasikan untuk melakukan pencampuran secara tank mix dengan herbisida atrazin untuk meningkatkan kinerja produk.

Respon dari pengkombinasian herbisida dibagi menjadi tiga jenis. Respon pertamaya itu bersifat aditif, yang ditandai dengan samanya hasil yang diperoleh terhadap pengendalian gulma baik ketika herbisida tersebut diaplikasikan tunggal maupun dicampur herbisida dengan bahan aktif yang berbeda. Respon kedua yaitu bersifat antagonis, hal ini terjadi jika campuran kedua bahan aktif memberikan respon yang lebih rendah dari yang diharapkan. Sedangkan respon yang ketiga adalah bersifat sinergis, dimana respon dari pencampuran herbisida lebih tinggi dari pada respon yang diharapkan (Craft and Robbins dalamTampubolon, 2009).

Dalam pengujian campuran herbisida dengan cara kerja yang sejenis digunakan metode analisis Isobol, sedangkan untuk pengujian herbisida dengan cara kerja yang berbeda digunakan model MSM (Multiple Survival Model). Oleh karena cara kerja herbisida atrazin berbeda dengan herbisida mesotrion maka metode pengujian campuran yang digunakan adalah menggunakan model MSM (Cobb,2000).

\section{METODE}

Alat yang digunakan dalam penelitian ini antara lain knapsack sprayer dengan nozzle kipas berwarna biru, gelas ukur, gelas piala, pipet ukur, oven, timbangan, serta gelas plastik sebagai pot percobaan dengan diameter $6,75 \mathrm{~cm}$ dan tinggi $11,5 \mathrm{~cm}$. Sedangkan bahan yang digunakan adalah herbisida berbahan aktif kombinasi (atrazin dan mesotrion) dan herbisida berbahan aktif tunggal komponen campuran dengan kandungan atrazin dan mesotrion, media tanam dalam pot dengan komposisi tanah dan kompos 1:1, serta bibit gulma yang terdiri dari gulma golongan rumput (Paspalumconjugatum), golongan teki (Cyperuskyllingia), dan golongan daun lebar (Asystasiagangetica).

Penelitian ini disusun dalam Rancangan Acak Lengkap (RAL). Perlakuan terdiri dari tiga jenis herbisida dengan enam tingkat dosis bahan aktif, yaitu herbisida tunggal atrazin $500 \mathrm{~g} \mathrm{l}^{-1}(0,76$, 152, 304, 608, dan $\left.1.215 \mathrm{~g} \mathrm{ha}^{-1}\right)$, mesotrion $50 \mathrm{~g} \mathrm{l}^{-1}\left(0,11,22,43,86\right.$, dan $\left.172 \mathrm{~g} \mathrm{ha}^{-1}\right)$, dan campuran 
herbisida dari atrazin $500 \mathrm{~g} \mathrm{l}^{-1}+$ mesotrion $50 \mathrm{~g} \mathrm{l}^{-1}\left(0,28,56,112,225\right.$, dan $\left.450 \mathrm{~g} \mathrm{ha}^{-1}\right)$. Masingmasing perlakuan diulang sebanyak enam kali. Untuk menguji homogenitas ragam digunakan uji Bartlet dan aditivitas data diuji dengan menggunakan uji Tukey. Jika asumsi terpenuhi, maka data akan dianalisis dengan sidik ragam dan uji perbedaan nilai tengah perlakuan akan diuji dengan uji Beda Nyata Terkecil (BNT) pada taraf 5\%.

Data bobot kering bagian segar gulma dikonversi kedalam persen kerusakan. Data persen kerusakan ditransformasi dalam bentuk logaritmik untuk mendapatkan persamaan regresi serta menghitung $\mathrm{LD}_{50}$ dari masing-masing herbisida dan campurannya. Kriteria sifat pencampuran dapat diketahui dengan analisis menggunakan metode sebagai berikut:

Formulasi campuran herbisida dengan komponen dari herbisida-herbisida yang berbeda kelompok: (1) Dibuat persamaan probit dari masing-masing herbisida komponen dan campurannya, (2) dengan menggunakan persamaan probit ditentukan nilai harapan dari $\mathrm{LD}_{50}$-campuran dengan menggunakan persamaan:

$$
\text { P-campuran }=\mathrm{P}_{\mathrm{A}}+\mathrm{P}_{\mathrm{B}}-\mathrm{P}_{\mathrm{A}} \mathrm{P}_{\mathrm{B}}
$$

Dihitung nilai ko-toksisitas $=\left(\mathrm{LD}_{50}\right.$-harapan $/ \mathrm{LD}_{50}$-perlakuan $)$, Jika nilai ko-toksisitas $>$ atau $=1$ berarti campuran tersebut tidak bersifat antagonis.

\section{HASIL DAN PEMBAHASAN}

Data keracunan masing-masing herbisida pada gulma sasaran tercantum pada pengamatan gejala keracunan 1 MSA dan 2 MSA. Bobot kering yang diperoleh kemudian ditransformasi ke dalam bentuk persen kerusakan untuk menunjukkan seberapa besar masing-masing herbisida mampu merusak tubuh gulma. Nilai persen kerusakan dan dosis herbisida kemudian ditransformasi ke dalam bentuk probit dan $\log$ dosis untuk diperoleh persamaan regresi nya. Dengan persamaan regresi tersebut dapat diperoleh $\mathrm{LD}_{50}$ perlakuan dan $\mathrm{LD}_{50}$ harapan untuk menunjukkan sifat pencampuran.

\section{Gejala Keracunan}

Gejala keracunan yang terlihat pada setiap bahan aktif sama, yaitu adanya pemutihan (bleaching) pada daun gulma. Gejala pemutihan terakumulasi pada daun, terutama pada daun muda, dan tidak terlihat pemutihan pada bagian batang. Peningkatan dosis herbisida menyebabkan terjadinya peningkatan gejala keracunan. Gejala pemutihan disertai dengan mengering dan mati nya tubuh gulma. Herbisida atrazin mampu mematikan tubuh gulma pada dosis $1.215 \mathrm{~g} \mathrm{ha}^{-1}$. Herbisida mesotrion mampu mematikan tubuh gulma mulai dari dosis $22 \mathrm{~g} \mathrm{ha}^{-1}$. Sedangkan herbisida atrazin + mesotrion mampu mematikan tubuh gulma pada dosis $450 \mathrm{~g} \mathrm{ha}^{-1}$. Gejala Keracunan Gulma Asystasia gangetica pada masing-Masing Herbisida dan tingkat dosis disajikan dalam gambar 1.

Gambar 2 menunjukkan bahwa gejala pemutihan tidak banyak terlihat. Pada herbisida atrazin, gejala pemutihan sedikit terlihat pada dosis $76 \mathrm{~g} \mathrm{ha}^{-1}$ dan $152 \mathrm{~g} \mathrm{ha}^{-1}$. Gejala yang terlihat pada dosis herbisida atrazin yang lebih tinggi berupa pencoklatan daun dan mengeringnya tubuh gulma. Herbisida atrazin mampu mengendalikan gulma secara menyeluruh mulai dari dosis $608 \mathrm{~g} \mathrm{ha}^{-1}$. Pada herbisida mesotrion, gejala pemutihan hanya terlihat pada dosis $11 \mathrm{~g} \mathrm{ha}^{-1}$. Pada perlakuan dengan dosis lebih tinggi terlihat adanya daun-daun gulma yang mengering. Gulma telah mengering seluruhnya pada dosis herbisida mesotrion sebesar $86 \mathrm{~g} \mathrm{ha}^{-1}$. Sedangkan pada herbisida atrazin + mesotrion, justru yang banyak terlihat hanya pemutihan daun dengan sidikit disertai mengeringnya 
daun tersebut. Pada dosis tertinggi yaitu sebesar $450 \mathrm{~g} \mathrm{ha}^{-1}$ herbisida campuran telah mampu mengendalikan gulma secara menyeluruh.

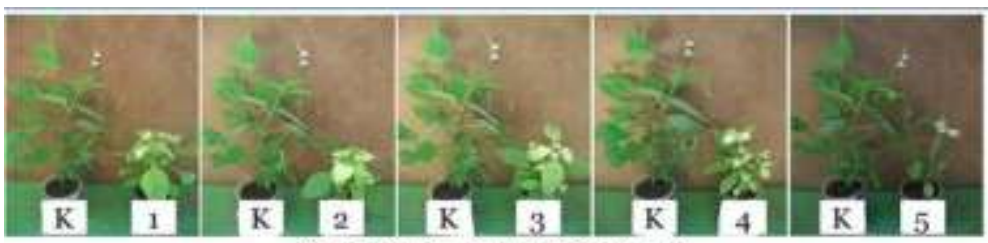

Gejala Kencunan Herbisida Atrazin

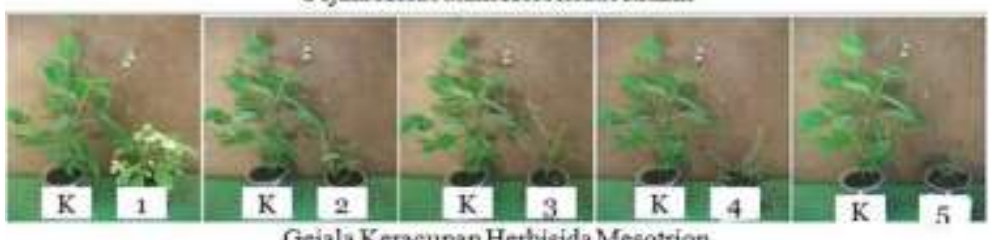

Gejala Keracunan Herbisida Mesotrion

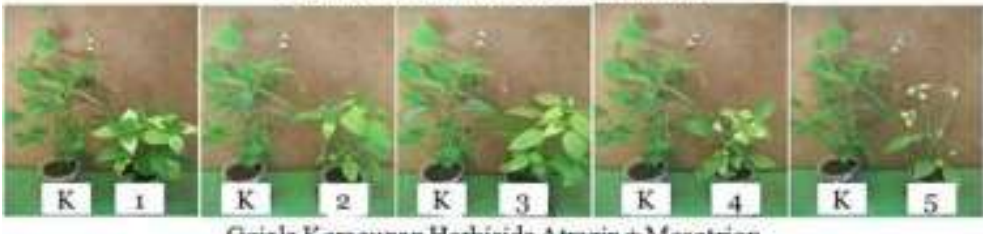

Gejala Keracunan Herbisida Atrazin + Mesotrion
Keterangan:

HerbisidaAtrazin

$\mathrm{K}=$ Kontrol

$1=\operatorname{dosis} 76 \mathrm{~g} \mathrm{ha}^{1}$

2 -dosis $152 \mathrm{~g} \mathrm{ha}^{-1}$

3 -dosis $304 \mathrm{~g} \mathrm{ha}^{-1}$

$4=\operatorname{dosis} 608 \mathrm{~g} \mathrm{ha}^{-1}$

$5=$ dosis $1215 \mathrm{gha}^{\prime}$

Herbisida Mesotrion

$\mathrm{K}=\mathrm{Kontrol}$

1 -dosis $11 \mathrm{~g} \mathrm{ha}^{-1}$

$2=$ dosis $22 \mathrm{~g} \mathrm{ha}^{-1}$

$3=$ dosis $43 \mathrm{~g} \mathrm{ha}$

$4=$ dosis $86 \mathrm{~g} \mathrm{ha}^{-}$

$5=$ dosis $172 \mathrm{~g} \mathrm{hat}^{-1}$

Herbisida Atrazin + Mesotrion

$\mathrm{K}=$ Kontrol

$1=\operatorname{dosis} 28 \mathrm{~g} \mathrm{ha}^{-1}$

$2=$ dosis $56 \mathrm{~g} \mathrm{ha}^{-1}$

$3=$ dosis $112 \mathrm{~g} \mathrm{ha}^{-1}$

$4=$ dosis $225 \mathrm{~g} \mathrm{ha}^{-1}$

$5=$ dosis $450 \mathrm{~g} \mathrm{ha}^{-1}$

Gambar 1. Perbandingan Gejala Keracunan Gulma Asystasia gangetica pada masing-Masing Herbisida

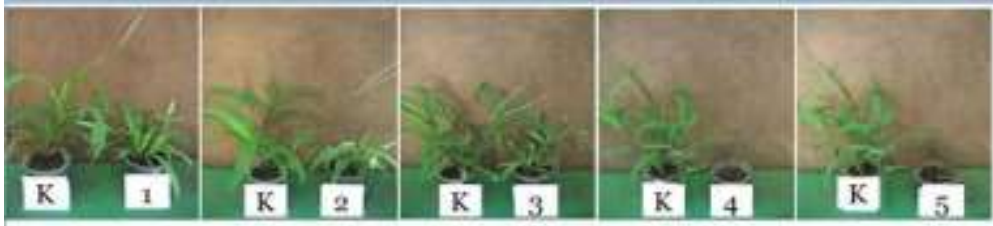

Gejala Keracunan Herbisida Atrazin

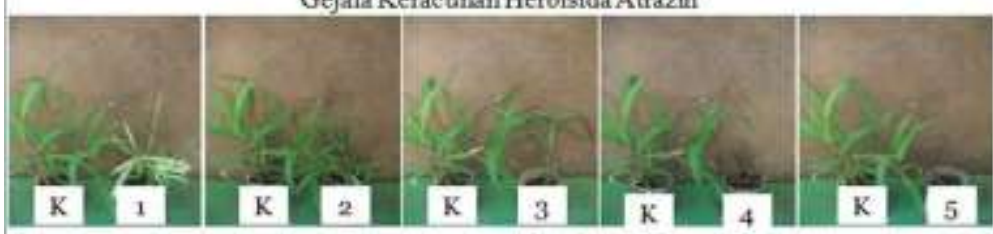

Gejala Keracunan Herbisida Mesotrion

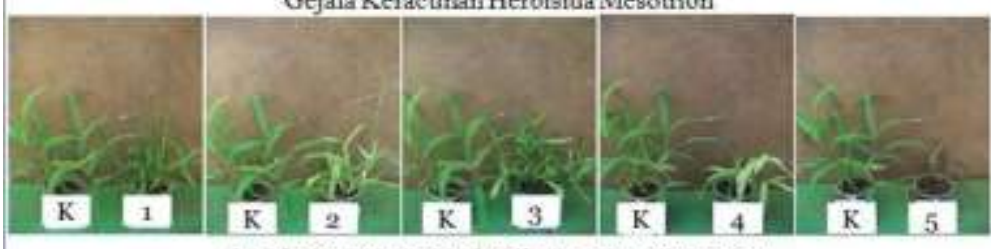

Gejala Keracunan Herbisida Atrazin + Mesotrion
Keterangan:

HerbisidaAtrazin

$\mathrm{K}=$ Kontrol

$1=$ dosis $76 \quad \mathrm{~g} \mathrm{ha} \cdot$

2 -dosis $152 \mathrm{~g} \mathrm{ha}^{-1}$

3 -dosis $304 \mathrm{~g} \mathrm{ha}^{-1}$

$4=$ dosis $608 \mathrm{~g} \mathrm{ha}^{-1}$

$5=$ dosis $1215 \mathrm{gha}^{1}$

Herbisida Mesotrion.

$\mathrm{K}=\mathrm{Kontrol}$

1 -dosis $11 \mathrm{~g} \mathrm{ha}-1$

$2=$ dosis $22 \mathrm{~g} \mathrm{ha}^{-1}$

$3=$ dosis 43 ghat

$4=\operatorname{dosis} 86 \mathrm{~g} \mathrm{ha}^{-1}$

$5=$ dosis $172 \mathrm{~g} \mathrm{ha}+1$

Herbisida Atrazin + Mesotrion

$\mathrm{K}=$ Kontrol

$1=$ dosis $28 \mathrm{~g} \mathrm{ha}^{-1}$

$2=$ dosis $56 \mathrm{~g} \mathrm{ha}^{-1}$

$3=$ dosis $112 \mathrm{~g} \mathrm{ha}^{-1}$

$4=$ dosis $225 \mathrm{~g} \mathrm{ha}^{-1}$

$5=$ dosis $450 \mathrm{~g} \mathrm{ha}^{-1}$

Gambar 2. Perbandingan Gejala Keracunan Gulma Paspalum conjugatum pada Masing-Masing Herbisida 


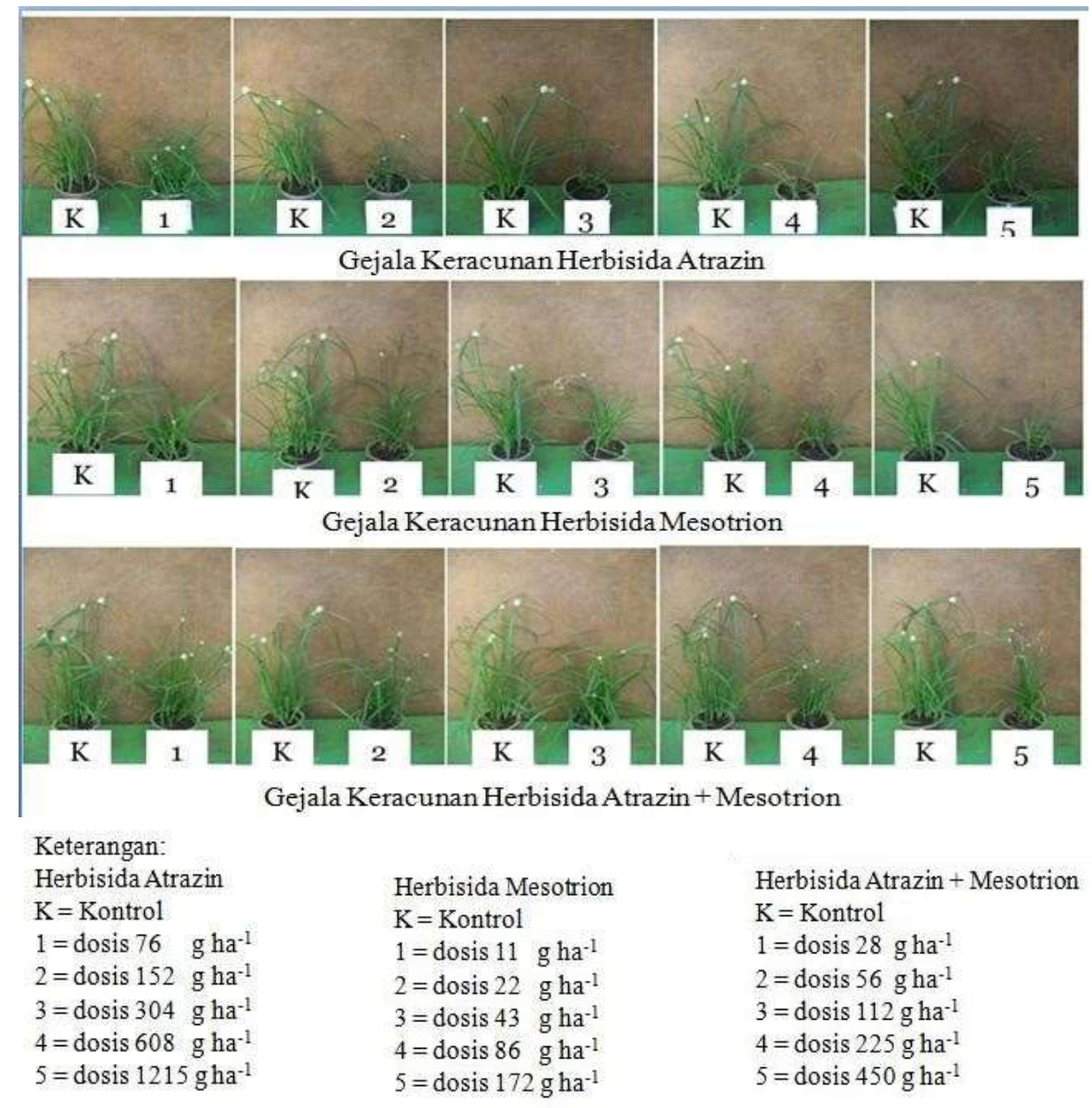

Gambar 3. Perbandingan Gejala Keracunan Gulma Cyperus kyllingia pada Masing-Masing Herbisida

\section{Analisis Kerusakan Gulma}

Semakin besar gejala kerusakan yang terlihat, maka bobot kering yang diperoleh menjadi semakin kecil. Bobot kering tersebut kemudian ditransformasi ke dalam bentuk persen keracunan untuk melihat seberapa besar masing-masing herbisida pada setiap dosis perlakuan menimbulkan kerusakan pada gulma. Data persen kerusakan ketiga jenis gulma tersebut selanjutnya dirata-rata. Hasil rata-rata persen kerusakan ketiga jenis gulma dapat dilihat pada Tabel 1 . Tabel 1 menunjukkan bahwa terjadi peningkatan kerusakan pada setiap peningkatan dosis bahan aktif. Berdasarkan rata-rata yang diperoleh, herbisida atrazin + mesotrion mampu menimbulkan kerusakan gulma sebesar $61,14 \%$ pada dosis tertinggi yaitu $450 \mathrm{~g} \mathrm{ha}^{-1}$.

Herbisida atrazin mampu menimbulkan kerusakan gulma terbesar pada dosis $608 \mathrm{~g} \mathrm{ha}^{-1}$ yaitu sebesar $83,72 \%$. Serta herbisida mesotrion menimbulkan kerusakan gulma lebih besar dibandingkan kedua herbisida lainnya yaitu sebesar $89,24 \%$ pada dosis $172 \mathrm{~g} \mathrm{ha}^{-1}$. Hasil ini sesuai dengan pengamatan gejala keracunan dimana herbisida mesotrion mampu menimbulkan gejala keracunan yang paling besar. 
Jurnal Penelitian Pertanian Terapan

Tabel 1. Rata-Rata Persen Kerusakan Ketiga Jenis Gulma

\begin{tabular}{ccccccccc}
\hline Perlakuan & Dosis $\left(\mathrm{g} \mathrm{ha}^{-1}\right)$ & 1 & 2 & 3 & 4 & 5 & 6 & Rata rata \\
\hline \multirow{5}{*}{ Atrazin + Mesotrion } & 0 & 0,00 & 0,00 & 0,00 & 0,00 & 0,00 & 0,00 & 0,00 \\
& 28 & 33,36 & 16,53 & 21,76 & 28,55 & 47,24 & 30,16 & 29,60 \\
& 56 & 56,80 & 27,68 & 29,56 & 17,46 & 12,20 & 25,17 & 28,14 \\
& 112 & 22,65 & 33,93 & 26,74 & 37,39 & 12,54 & 29,65 & 27,15 \\
& 225 & 67,01 & 45,09 & 73,28 & 47,03 & 36,70 & 48,38 & 52,91 \\
& 450 & 77,42 & 66,67 & 26,63 & 53,64 & 78,22 & 64,26 & 61,14 \\
\hline \multirow{5}{*}{ Atrazin } & 0 & 0,00 & 0,00 & 0,00 & 0,00 & 0,00 & 0,00 & 0,00 \\
& 76 & 28,83 & 44,02 & 75,87 & 43,66 & 26,82 & 50,08 & 44,88 \\
& 152 & 51,81 & 57,67 & 53,64 & 62,74 & 50,49 & 59,77 & 56,02 \\
& 304 & 65,96 & 81,32 & 80,05 & 70,11 & 71,20 & 58,39 & 71,17 \\
& 608 & 88,03 & 92,41 & 85,82 & 81,91 & 78,80 & 75,36 & 83,72 \\
Mesotrion & 1215 & 72,70 & 81,13 & 76,43 & 73,18 & 85,23 & 76,65 & 77,55 \\
\hline & 0 & 0,00 & 0,00 & 0,00 & 0,00 & 0,00 & 0,00 & 0,00 \\
& 11 & 41,56 & 53,41 & 49,86 & 34,29 & 18,07 & 39,70 & 39,48 \\
& 22 & 49,34 & 71,25 & 69,55 & 67,35 & 57,08 & 54,75 & 61,55 \\
& 43 & 77,43 & 79,33 & 68,40 & 56,75 & 67,07 & 54,90 & 67,32 \\
& 86 & 45,60 & 58,44 & 67,87 & 77,76 & 75,98 & 71,42 & 66,18 \\
& 172 & 94,31 & 90,10 & 79,64 & 85,05 & 97,03 & 89,28 & 89,24 \\
\hline
\end{tabular}

\section{Nilai Probit}

Nilai probit digunakan untuk mengetahui hubungan antara dosis perlakuan dengan persen kerusakan yang ditimbulkan oleh masing-masing herbisida. Dosis herbisida diubah ke dalam bentuk logaritmik sedangkan persen kerusakan diubah ke dalam nilai probit. Nilai probit yang dihasilkan kemudian digunakan untuk mencari persamaan regresi linier sehingga diketahui nilai $\mathrm{LD}_{50}$ perlakuan dan $\mathrm{LD}_{50}$ harapan. Tabel 2 merupakan rata-rata persen kerusakan yang telah dokonversi ke dalam nilai probit.

$\mathrm{LD}_{50}$

Berdasarkan nilai probit diperoleh persamaan regresi linier sederhana yaitu $\mathrm{Y}=\mathrm{a}+\mathrm{bX}$, dimana $\mathrm{Y}$ adalah nilai probit dari persen kerusakan gulma gabungan, dan $\mathrm{X}$ adalah log dosis perlakuan herbisida. Setelah diperoleh persamaan tersebut maka nilai $\mathrm{LD}_{50}$ dapat dihitung yang tercantum pada Tabel 3. Nilai tersebut menunjukkan dosis perlakuan yang mampu menimbulkan kerusakan gulma sebesar 50\%. Untuk mengetahui LD50 adalah dengan memasukkan nilai Y ke dalam persamaan regresi sebesar 5. Nilai 5 tersebut merupakan nilai probit dari $50 \%$. Nilai $X$ yang diperoleh dalam persamaan tersebut masih berupa log dosis sehingga perlu dikembalikan ke dalam antilog.

Aplikasi herbisida atrazin memerlukan dosis sebesar $88,21 \mathrm{~g} \mathrm{ha}^{-1}$, sedangkan perlakuan herbisida mesotrion memerlukan dosis sebesar 17,05 $\mathrm{g} \mathrm{ha}^{-1}$. Perlakuan aplikasi herbisida campuran atrazin + mesotrion memerlukan dosis sebesar 257,48 $\mathrm{g} \mathrm{ha}^{-1}$. Nilai dosis tersebut merupakan gabungan dosis dari masing-masing komponen bahan aktif, dengan rasio campuran komponen bahan aktif atrazin : mesotrion sebesar $10: 1$ sebagaim,ana disajikan dalam tabel 3 . 
Nana Ratna Wati dkk: Uji Efektifitas Herbisida Atrazin, Mesotrion, dan Campuran Atrazin+Mesotrion...

Tabel 2. Konversi Persen Kerusakan Rata-Rata ke dalam Nilai Probit

\begin{tabular}{ccccccccc}
\hline Perlakuan & Log Dosis & 1 & 2 & 3 & 4 & 5 & 6 & rata-rata \\
\hline \multirow{5}{*}{ Atrazin + Mesotrion } & 1,45 & 4,57 & 4,03 & 4,22 & 4,43 & 4,93 & 4,48 & 4,44 \\
& 1,75 & 5,17 & 4,41 & 4,46 & 4,06 & 3,83 & 4,33 & 4,38 \\
& 2,05 & 4,25 & 4,59 & 4,38 & 4,68 & 3,85 & 4,47 & 4,37 \\
& 2,35 & 5,44 & 4,88 & 5,62 & 4,93 & 4,66 & 4,96 & 5,08 \\
& 2,65 & 5,75 & 5,43 & 4,38 & 5,09 & 5,78 & 5,37 & 5,30 \\
\hline \multirow{5}{*}{ Atrazin } & 1,88 & 4,44 & 4,85 & 5,70 & 4,84 & 4,38 & 5,00 & 4,87 \\
& 2,18 & 5,05 & 5,19 & 5,09 & 5,32 & 5,01 & 5,25 & 5,15 \\
& 2,48 & 5,41 & 5,89 & 5,84 & 5,53 & 5,56 & 5,21 & 5,57 \\
& 2,78 & 6,18 & 6,43 & 6,07 & 5,91 & 5,80 & 5,69 & 6,01 \\
& 3,08 & 5,60 & 5,88 & 5,72 & 5,62 & 6,05 & 5,73 & 5,77 \\
\hline \multirow{5}{*}{ Mesotrion } & 1,03 & 4,79 & 5,09 & 5,00 & 4,60 & 4,09 & 4,74 & 4,72 \\
& 1,33 & 4,98 & 5,56 & 5,51 & 5,45 & 5,18 & 5,12 & 5,30 \\
& 1,63 & 5,75 & 5,82 & 5,48 & 5,17 & 5,44 & 5,12 & 5,46 \\
& 1,94 & 4,89 & 5,21 & 5,46 & 5,76 & 5,71 & 5,57 & 5,43 \\
& 2,24 & 6,58 & 6,29 & 5,83 & 6,04 & 6,89 & 6,24 & 6,31 \\
\hline
\end{tabular}

Tabel 3. Persamaan Regresi Probit dan Nilai $\mathrm{LD}_{50}$ perlakuan: $\mathrm{Y}=$ Nilai Probit dari Rata-rata Persen Kerusakan 6 Jenis Gulma, $\mathrm{X}=\mathrm{Log}$ Dosis

\begin{tabular}{cccc}
\hline Formulasi Herbisida & Persamaan Garis & Nilai ${ }^{2}(\%)$ & $\begin{array}{c}\mathrm{LD}_{50} \text { perlakuan } \\
\left(\mathrm{g} \mathrm{ha}^{-1}\right)\end{array}$ \\
\hline Atrazin+Mesotrion & $\mathrm{Y} 3=0,801 \mathrm{X}+3,069$ & 0,744 & 257,48 \\
Atrazin & $\mathrm{Y} 1=0,881 \mathrm{X}+3,286$ & 0,824 & 88,21 \\
Mesotrion & $\mathrm{Y} 2=1,105 \mathrm{X}+3,639$ & 0,847 & 17,05 \\
\hline
\end{tabular}

\section{Model MSM (Multiplicative Survival Model)}

Sifat campuran herbisida diperoleh dengan membandingkan nilai $\mathrm{LD}_{50}$ harapan dengan nilai $\mathrm{LD}_{50}$ perlakuan. Diketahuin ilai $\mathrm{LD}_{50}$ perlakuan campuran herbisida $\mathrm{A}$ (atrazin) $+\mathrm{M}$ (mesotrion) sebesar 257,48 $\mathrm{g} \mathrm{ha}^{-1}$. perbandingan komponen campuran $\mathrm{A}: \mathrm{M}=10: 1$. Nilai $\mathrm{LD}_{50}$ perlakuan masing-masing komponen: Atrazin $\left(\mathrm{X}_{1}\right)=234,07 \mathrm{~g} \mathrm{ha}^{-1}$ dan Mesotrion $\left(\mathrm{X}_{2}\right)=23,41 \mathrm{~g} \mathrm{ha}^{-1}$

$\mathrm{LD}_{50}$ harapan dihitung berdasarkan perubahan nilai komponen campuran di atas $\left(\mathrm{X}_{1}\right.$ dan $\left.\mathrm{X}_{2}\right)$ dalam proporsi perbandingan tetap ( $\mathrm{A}: \mathrm{B}=10: 1)$ hingga perubahan nilai dosis tersebut dapat menyebabkan kerusakan gulma sebesar 50\%. Nilai dosis komponen campuran dimasukkan ke dalam persamaan regresi linier probit dari masing-masing herbisida tunggal dalam bentuk logaritmik, sehingga dengan mengacu pada tabel probit dapat diperoleh nilai persen kerusakan gulma yang disebabkan baik oleh atrazin maupun oleh mesotrion

- \% kerusakan akibat atrazin $\quad\left(\mathrm{Y}_{1}\right) \quad=64,5 \%\left(\mathrm{P}_{\mathrm{A}}\right)$

- $\%$ kerusakan akibat mesotrion $\left(\mathrm{Y}_{2}\right) \quad=56,2 \%\left(\mathrm{P}_{\mathrm{B}}\right)$

- \% kerusakan campuran herbisida $\left.\quad=\mathrm{P}_{(\mathrm{AB}}\right)=\mathrm{P}_{\mathrm{A}}+\mathrm{P}_{\mathrm{B}}-\mathrm{P}_{\mathrm{A}} \mathrm{P}_{\mathrm{B}}$

$=64,5+56,2-(36,25)$

$=84.45 \%$ 
Nilai tersebut mencapai lebih dari 50\%, sehingga dengan mengurangi dosis (mengubah nilai $\mathrm{X}_{1}$ dan $\mathrm{X}_{2}$ ) tersebut, maka diperoleh dosis dari masing-masing herbisida komponen campuran adalah sebesar:

- Atrazin $\left(\mathrm{X}_{1}\right)=46,79$

- Mesotrion $\left(\mathrm{X}_{2}\right) \quad=4,69$

Dengan dosis tersebut, maka kerusakan gulma oleh masing-masing komponen campuran (nilai probit) adalah sebesar:

- Atrazin $\left(\mathrm{Y}_{1}\right) \quad=4,7574$

- Mesotrion $\left(\mathrm{Y}_{2}\right) \quad=4,3806$

Jika dikonversi dalam bentuk anti-probit, maka kerusakan gulma oleh masing-masing komponen herbisida tersebut adalah sebesar:

- Atrazin $\left(\mathrm{Y}_{1}\right)=40,4 \% \quad\left(\mathrm{P}_{\mathrm{A}}\right)$

- Mesotrion $\left(\mathrm{Y}_{2}\right)=26,8 \% \quad\left(\mathrm{P}_{\mathrm{B}}\right)$

Tingkat kerusakan gulma 50\% (harapan) diketahui berdasarkan persamaan probit:

$$
\left.\mathrm{P}_{\mathrm{AB}}\right)=\mathrm{P}_{\mathrm{A}}+\mathrm{P}_{\mathrm{B}}-\mathrm{P}_{\mathrm{A}} \mathrm{P}_{\mathrm{B}} \quad \text { (nilai } \mathrm{P}_{\mathrm{A}} \mathrm{P}_{\mathrm{B}}=10,83 \text { ) }
$$

Persamaan probit: $\mathrm{P}\left({ }_{\mathrm{AB}}\right) \quad=40,4+26,8-10,83$

$$
=56,37 \%
$$

Jadi:

$$
\begin{array}{ll}
\mathrm{LD}_{50} \text { harapan } & =46,79+4,69=51,48 \mathrm{gha}^{-1} \\
\mathrm{LD}_{50} \text { perlakuan } & =234,07+23,41=257,48 \quad \mathrm{~g} \mathrm{ha}^{-1}
\end{array}
$$

Ko-toksisitas: $\mathrm{LD}_{50}$ harapan/ $\mathrm{LD}_{50}$ perlakuan $\quad=51,48 / 257,48$

$$
=0,2
$$

Berdasarkan hasil perhitungan dengan model MSM diatas, maka nilai $\mathrm{LD}_{50}$ perlakuan lebih besar daripada $\mathrm{LD}_{50}$ harapan, nilai ko-toksisitas $=0,2$ atau kurang dari satu $(<1)$.

\section{Interaksi Herbisida}

Sifat interaksi herbisida diperoleh dari nilai ko-toksisitas yang didapat. Nilai ko-toksisitas sebesar 0.2 atau kurang dari satu $(<1)$ menunjukkan bahwa campuran herbisida atrazin dan mesotrion bersifat antagonis pada gulma sasaran. Berdasarkan analisis model MSM diketahui bahwa campuran dua herbisida dengan bahan aktif atrazin dan mesotrion bersifat antagonis. Nilai harapan sebesar $51,48 \mathrm{~g} \mathrm{ha}^{-1}$ menunjukkan bahwa pada dosis tersebut herbisida campuran akan mampu mengendalikan $50 \%$ populasi keenam jenis gulma. Namun pada aplikasinya, dosis formulasi herbisida campuran sebesar $257,48 \mathrm{~g} \mathrm{ha}^{-1}$ lah yang mampu mengendalikan $50 \%$ populasi gulma.

Sifat antagonis yang ditunjukkan oleh analisis tersebut sesuai dengan perhitungan pada setiap jenis gulma. Dengan menggunakan log dosis herbisida dan rata-rata persen kerusakan yang telah dirubah ke dalam nilai probit untuk setiap jenis gulma diketahui bahwa dosis yang diperlukan oleh herbisida campuran untuk menghasilkan kerusakan sebesar 50\% lebih tinggi jika dibandingkan dengan pengaplikasian komponen campuran herbisida secara tunggal

\section{KESIMPULAN}

Kesimpulan yang diperoleh dari penelitian ini adalah bahwa pencampuran herbisida atrazin $500 \mathrm{~g} \mathrm{l}^{-1}+$ mesotrion $50 \mathrm{~g} \mathrm{l}^{-1}$ memiliki nilai $\mathrm{LD}_{50}$ harapan sebesar $51,48 \mathrm{~g} \mathrm{ha}^{-1}$ dan $\mathrm{LD}_{50}$ perlakuan 
Nana Ratna Wati dkk: Uji Efektifitas Herbisida Atrazin, Mesotrion, dan Campuran Atrazin+Mesotrion...

sebesar 257,48 $\mathrm{g} \mathrm{ha}^{-1}$ dengan nilai ko-toksisitas sebesar 0,2 (ko-toksisitas < 1) sehingga campuran bersifat antagonis.

\section{DAFTAR PUSTAKA}

Cobb A. H, and R. C. Kirkwood. 2000. Herbicides and Their Mechanisms of Action. Sheffield Academic Press. 295 hlm.

Cousens, R. and M. Mortimer. 1995. Dynamics of Weed Populations. Cambridge University Press, Cambridge. $332 \mathrm{hlm}$.

Cox, C. 2001. Atrazine: Toxicology. Journal of Pesticide Reform. Northwest Coalition for Alternatives to Pesticides/NCAP. 21 (2): 12 - 20

Hanh, R. R. and P. J. Stachowski.2002. Mesotrione-a new herbicide and mode of action. Department of Crop and Soil Science. Cornell Univeristy. Diakses melalui http://css.cals.cornell.edu/extension/cropping-up-archive/wcu_vol12n062002a1mesotrione.pdf pada tanggal 4 Juni 2013.

Lewis, S. E., B. Schaffelke, M. Shaw, Z. T. Bainbridge, K. W. Rohde, K. Kennedy, A. M. Davis, B. L. Masters, M. J. Devlin, J. F. Mueller, dan J. E. Brodie. 2012. Assessing the additive risks of PSII herbicide exposure to the Great Barrier Reef. Marine Pollution Bulletin 65 (2012): 280291

Sembodo, D. R. J. 2010. Gulma dan Pengelolaannya. Graha Ilmu. Yogyakarta. 166 hlm.

Tampubolon, I. 2009. Uji Efektifitas Herbisida Tunggal Maupun Campuran dalam Pengendalian Stenochlaena palustris di Gawangan Kelapa Sawit. Skripsi. Universitas Sumatera Utara. Medan. $55 \mathrm{hlm}$.

Tjitrosoedirdjo, S., I. H. Utomo, dan J. Wiroatmojo. 1984. Pengelolaan Gulma di Perkebunan. P.T. Gramedia. Jakarta. 209 hlm.

Wikipedia, 2014. Herbicide.Diakses melalui http:// en.wikipedia.org/wiki/ herbicide pada tanggal 28 Juni 2014. 